\title{
Factors associated with non-adherence to highly active antiretroviral therapy in Nairobi, Kenya
}

\author{
Samwel N Wakibi ${ }^{1 *}$, Zipporah W Ng'ang'a ${ }^{1}$ and Gabriel G Mbugua ${ }^{2}$
}

\begin{abstract}
Background: Antiretroviral therapy (ART) requires high-level (> 95\%) adherence. Kenya is rolling out ART access programmes and, issue of adherence to therapy is therefore imperative. However, published data on adherence to ART in Kenya is limited. This study assessed adherence to ART and identified factors responsible for non adherence in Nairobi.

Methods: This is a multiple facility-based cross-sectional study, where 416 patients aged over 18 years were systematically selected and interviewed using a structured questionnaire about their experience taking ART. Additional data was extracted from hospital records. Patients were grouped into adherent and non-adherent based on a composite score derived from a three questions adherence tool developed by Center for Adherence Support Evaluation (CASE). Multivariate regression model was used to determine predictors of non-adherence.

Results: Overall, 403 patients responded; 35\% males and 65\% females, 18\% were non-adherent, and main (38\%) reason for missing therapy were being busy and forgetting. Accessing ART in a clinic within walking distance from home $(\mathrm{OR}=2.387, \mathrm{Cl} .95=1.155-4.931 ; p=0.019)$ and difficulty with dosing schedule $(\mathrm{OR}=2.310, \mathrm{Cl} .95=1.211$ $4.408, p=0.011)$ predicted non-adherence.

Conclusions: The study found better adherence to HAART in Nairobi compared to previous studies in Kenya. However, this can be improved further by employing fitting strategies to improve patients' ability to fit therapy in own lifestyle and cue-dose training to impact forgetfulness. Further work to determine why patients accessing therapy from ARV clinics within walking distance from their residence did not adhere is recommended.
\end{abstract}

\section{Background}

Antiretroviral treatment success depends on sustainable high rates of adherence to medication regimen of ART [1]. However, significant proportions of HIV-infected patients do not reach high levels of adherence and this can lead to devastating public health problems. Mills et $a l$ in a meta-analysis study found a combined continental adherence to ART of $64 \%$ with $55 \%$ adherence in North America and 77\% in Africa. Twenty four percent non-adherence has been reported in Southwest Ethiopia [2], 22\% in Cote d'Ivore [3] and 13\% in Cameroon [4]. Byakika et al [5] reported 68\% adherence to HIV treatment in Uganda, 54\% in Nigeria [6] and 63\% in South Africa [7]. Non-adherence to ART has been associated

\footnotetext{
* Correspondence: wambui@myway.com

${ }^{1}$ Institute of Tropical Medicine and Infectious Diseases (ITROMID), Jomo Kenyatta University of Agriculture and Technology (JKUAT), P.O. Box 62000 00200 Nairobi, Kenya

Full list of author information is available at the end of the article
}

to diverse factors including patient related factors, health condition/disease, health care system and healthcare teams, therapy/treatment and Socio-economic factors [5,6,8-10]. Kenya is rolling out a free HAART programme to increase access and by 2009, 336980 patients were accessing [11], and adherence reported vary from $48 \%$ in Kibera, Nairobi [12]; 56.8\% in Eldoret [13] and 64\% in Mombasa [14].

\section{Statement of the research hypothesis}

Published data about factors that influence non-adherence to ART in Kenya is limited. To generate this knowledge, this study determined prevalence of nonadherence and associated factors.

It was hypothesized that:

$\mathrm{H}_{0}$ - there are no factors association with non-adherence to HAART among HIV patients in Nairobi, Kenya.

\section{Biomed Central}




\section{Method \\ Setting}

This study was conducted at HIV/AIDS treatment centre in the Kenyatta National Hospital, Kenya Medical Research Institute (KEMRI) and Riruta Health centre in Nairobi, Kenya.

\section{Population sample}

The sample was of 416 HIV+ outpatients aged 18 years or more on free HAART for three or more months between November, 2008 and April, 2009.

\section{Design}

Cross-sectional observational study design collected data from systematically selected patients as they visited the three purposively selected HIV clinics to refill. The patients were interviewed about their health beliefs, health system interaction, ARV therapy uptake and reasons for non-adherence. CASE adherence tool [15] was used to determine adherence. Additional data about time on ARV and age were extracted from hospital records.

CASE Adherence tool was developed by the New York Academy of Medicine's (NYAM) Center for Adherence Support Evaluation (CASE). It consists of three adherence questions: (rated on a likert scale) "How often do you feel that you have difficulty taking your HIV medications on time? On average, how many days PER WEEK would you say that you missed at least one dose of your HIV medications? When was the last time you missed at least one dose of your HIV medications?"A higher composite score signify better adherence.

The CASE Adherence Index correlated strongly with the AACTG three-day self-reported adherence data $(p<$ 0.001 ), is more strongly associated with HIV outcomes and performed as well as the three-day self-report when predicting CD4 cell count status[16].

\section{Data analysis}

Patient's scores in the CASE adherence tool were summed up to obtain a composite score that ranged from 3 to 16 points. Patients with Index score $\leq 10$ points were classified as non-adherent and > 10 adherent [15]. Other data generated from the questionnaire were keyed into SPSS and analyzed for frequencies, cross-tabulations, chi-square test, and multivariate logistic regression to determine predicting factors. A p-value $<0.05$ was considered significant in all statistical analysis.

\section{Ethical considerations}

Ethical clearance was given by the KEMRI's National Ethical Review Committee, and permission to conduct the research was obtained from the participating clinics. Consent was obtained both verbally and in writing in either English or Kiswahili. To ensure confidentiality, interviews were conducted in private and strict control maintained over data.

\section{Results}

\section{Characteristics of the respondents}

Characteristics of the respondents are presented in Table 1. Out of the 416 patients interviewed, 403 answered all adherence questions and were analyzed. Females were 262 (65\%) and males 141 (35\%); their age ranged between 18 and 64 years old. Most patients were married 213 (53\%); 246 (61\%) had at least secondary education, 145 (36\%) had primary education and 10 (3\%) had no formal education. Three hundred (75\%) respondents earned less than $\$ 120$ per month; and most $271(67 \%)$ lived in $1-3$ rooms and the rest in a more than 1 bedroom house.

Majority respondents 281 (70\%) had a CD4 count of more than 200 cells $/ \mathrm{ml}, 280(80 \%)$ had more than 1 year experience with ART and 138(43\%) had not had side effects. ART knowledge was extremely high (100), but only 197 (49\%) stated condom use as important, $(82 \%)$ reported adherence and $(68 \%)$ nutrition.

Most 321(80\%) patients lived with family, 329(82\%) had disclosed their HIV status and 282(79\%) reported getting social support. Sixty nine (17\%) patients found therapy disruptive of their life while 186 (46\%) were embarrassed taking ARV. Most respondents 154 (38\%) reported being busy and forgetting as the reason for missing therapy, while 197 (49\%) had never failed to take medicine.

\section{Adherence to HAART}

Seventy two (18\%) respondents were non-adherence based on CASE adherence method, while74 (18\%) reported missing at least one dose of therapy per week ( $<95 \%$ adherence) (Table 2). Adherence to HAART among respondents differed significantly at $p$-value $<$ 0.05 by age $(p=0.017)$, difficulty fitting therapy in own daily schedule $(p=0.006)$, social support $(p=$ $0.015)$, period on therapy $(p=0.002)$, self report missed therapy $(p=0.001)$, proximity to clinic where respondents refilled $(p=0.003)$ and time spent at clinic per visit $(p=0.000)$ by univariate analysis (Table $1)$. However, only having difficult fitting therapy in own schedule $(\mathrm{OR}=2.310, \mathrm{CI} .95=1.211-4.408, p=$ $0.011)$ and proximity to clinic where respondents refilled $(\mathrm{OR}=2.387, \mathrm{CI} .95=1.155-4.931, p=0.019)$ predicted non-adherence by multivariate analysis (Table 3). Main reason for missing therapy was being busy and forgetting. 
Table 1 Characteristics of respondents

\begin{tabular}{|c|c|c|c|c|}
\hline \multirow{2}{*}{$\begin{array}{l}\text { Characteristics } \\
\text { Variable }\end{array}$} & \multicolumn{3}{|l|}{ Adherent } & \multirow[t]{2}{*}{$p$-value } \\
\hline & No; $n(\%)$ & & Total; $\boldsymbol{n}$ (\%) & \\
\hline & \multicolumn{3}{|c|}{ Socio-demographic characteristics } & \\
\hline \multicolumn{5}{|l|}{ Gender distribution } \\
\hline All & $72(18)$ & $331(82)$ & $403(100)$ & \\
\hline Males & $25(18)$ & $116(82)$ & $141(35)$ & 0.958 \\
\hline Females & $47(18)$ & $215(82)$ & $262(65)$ & \\
\hline \multicolumn{5}{|l|}{ Mean age } \\
\hline All & $37.6 \mathrm{yrs}$ & 40.2 yrs & 39.7 yrs & $0.017^{*}$ \\
\hline Male & $41.6 \mathrm{yrs}$ & 42.8 yrs & 42.6 yrs & 0.491 \\
\hline Female & 35.4 yrs & 38.8 yrs & 38.2 yrs & $0.012^{*}$ \\
\hline Marital status & & & & 0.225 \\
\hline Never married & $14(19)$ & $58(81)$ & $72(18)$ & \\
\hline Married & $40(19)$ & $173(81)$ & $213(53)$ & \\
\hline Divorced/Separate & $13(23)$ & $44(77)$ & $57(14)$ & \\
\hline Widowed & $5(9)$ & $52(91)$ & $57(14)$ & \\
\hline Missing & 0 & 4 & $4(1)$ & \\
\hline Ever widowed? & & & & 0.053 \\
\hline Yes & $5(9)$ & $52(91)$ & $57(14)$ & \\
\hline No & $67(20)$ & $275(80)$ & $342(85)$ & \\
\hline Education level & & & & 0.665 \\
\hline No education & $1(10)$ & $9(10)$ & $10(3)$ & \\
\hline Primary & $28(19)$ & $117(81)$ & 145(36) & \\
\hline Secondary & $32(16)$ & $168(84)$ & $200(50)$ & \\
\hline Post secondary & $10(22)$ & $36(78)$ & $46(11)$ & \\
\hline Missing & & & 2 & \\
\hline Monthly Income (USD) & & & & 0.734 \\
\hline Unemployed & $27(20)$ & $110(80)$ & 137(34) & \\
\hline$<60$ & $17(21)$ & $66(80)$ & $83(21)$ & \\
\hline $61-120$ & $11(14)$ & $69(86)$ & $80(20)$ & \\
\hline $121-180$ & $2(9)$ & $21(91)$ & $23(6)$ & \\
\hline $181-240$ & $5(19)$ & $22(82)$ & $27(7)$ & \\
\hline $241-600$ & $5(15)$ & $29(85)$ & $34(8)$ & \\
\hline $600+$ & $4(24)$ & $13(77)$ & $17(4)$ & \\
\hline Missing & & & 2 & \\
\hline Housing & & & & 0.275 \\
\hline $1 \mathrm{room}$ & $39(21)$ & $147(79)$ & 186(46) & \\
\hline $2-3$ rooms & $16(19)$ & $69(81)$ & $85(21)$ & \\
\hline 1 bedroom & $7(17)$ & $34(83)$ & $41(10)$ & \\
\hline 2 bedrooms & $4(8)$ & $48(92)$ & $52(13)$ & \\
\hline$\geq 3$ bedrooms & $6(15)$ & $33(85)$ & $39(10)$ & \\
\hline $1-3$ rooms & $55(20)$ & $216(80)$ & $271(67)$ & 0.068 \\
\hline \multirow[t]{2}{*}{$\geq 1$ bedrooms } & $17(13)$ & $115(87)$ & $132(33)$ & \\
\hline & \multicolumn{3}{|c|}{ Clinical characteristics } & \\
\hline CD4 cell count $\leq 200$ cells $/ \mathrm{ml}$ & & & & $0.025^{*}$ \\
\hline Yes & $25(26)$ & $71(74)$ & $96(24)$ & \\
\hline No & $44(16)$ & $237(84)$ & $281(70)$ & \\
\hline Missing & & & $26(6)$ & \\
\hline Time on ART & & & & $0.003^{*}$ \\
\hline 3 to 6 months & 13(37) & $22(63)$ & $35(9)$ & \\
\hline $6-12$ months & $18(21)$ & $69(79)$ & $87(22)$ & \\
\hline
\end{tabular}


Table 1 Characteristics of respondents (Continued)

\begin{tabular}{|c|c|c|c|c|}
\hline 1 to 2 years & $25(19)$ & $110(81)$ & $135(34)$ & \\
\hline 3 years + & $16(11)$ & 129(89) & $145(36)$ & \\
\hline Missing & & & 1 & \\
\hline \multicolumn{5}{|l|}{ Adverse effects } \\
\hline Nausea & $7(30)$ & $16(70)$ & $23(7)$ & 0.898 \\
\hline Vomiting & $1(8)$ & $11(92)$ & $12(4)$ & \\
\hline Diarrhea & $3(23)$ & $10(77)$ & $13(4)$ & \\
\hline Neuropathy & $3(10)$ & $27(90)$ & $30(9)$ & \\
\hline Itching & $6(23)$ & $20(77)$ & $26(8)$ & \\
\hline Rashes & $5(12)$ & $36(88)$ & $41(13)$ & \\
\hline Others & $6(15)$ & $33(85)$ & $39(12)$ & \\
\hline \multirow[t]{2}{*}{ None } & $24(17)$ & $114(83)$ & $138(43)$ & \\
\hline & \multicolumn{3}{|c|}{ ART knowledge } & \\
\hline \multicolumn{5}{|l|}{ Health literacy } \\
\hline Adhere & $57(17)$ & $272(83)$ & $329(82)$ & 0.55 \\
\hline Condom use & $35(18)$ & $162(82)$ & $197(49)$ & 0.959 \\
\hline Nutrition & $43(16)$ & $233(84)$ & $276(68)$ & 0.077 \\
\hline \multicolumn{5}{|l|}{ Use } \\
\hline Identify drugs & $72(18)$ & 331 (82) & $403(100)$ & \\
\hline Dosage & $72(18)$ & $330(82)$ & $402(100)$ & \\
\hline \multirow[t]{2}{*}{ Life-long therapy } & $72(18)$ & $328(82)$ & $400(99)$ & \\
\hline & \multicolumn{3}{|c|}{ Social support } & \\
\hline Living with & & & & 0.484 \\
\hline Family & $53(17)$ & 268(83) & $321(80)$ & \\
\hline Friends & $2(22)$ & 7 (78) & $9(2)$ & \\
\hline Alone & $16(22)$ & $56(78)$ & $72(18)$ & \\
\hline Living with children? & & & & 0.345 \\
\hline No & $10(14)$ & $62(86)$ & $72(18)$ & \\
\hline Yes & $50(18)$ & 235(82) & 285(71) & \\
\hline Have no children & $12(26)$ & $34(74)$ & $46(11)$ & 0.122 \\
\hline Has children & $60(17)$ & $297(83)$ & $357(89)$ & \\
\hline HIV Status disclosed & & & & 0.794 \\
\hline Yes: & $58(18)$ & $271(82)$ & $329(82)$ & \\
\hline No: & $13(18)$ & $60(81)$ & $73(18)$ & \\
\hline Reminded dose by & & & & 0.781 \\
\hline Self & $36(19)$ & $151(81)$ & 187(46) & \\
\hline Family & $35(17)$ & $176(83)$ & $211(52)$ & \\
\hline Friends & $1(20)$ & $4(80)$ & $5(1)$ & \\
\hline \multicolumn{5}{|l|}{ Level of social Support } \\
\hline Never (0\%) & $13(23)$ & $43(77)$ & $56(14)$ & \\
\hline Rarely (25\%) & $5(28)$ & $13(72)$ & $18(5)$ & \\
\hline Sometimes (50\%) & $12(26)$ & $34(74)$ & $46(11)$ & \\
\hline Often (75\%) & $17(22)$ & $60(78)$ & $77(19)$ & \\
\hline Always (> 75\%) & $24(18)$ & $181(88)$ & 205(51) & \\
\hline Missing & & & 1 & \\
\hline Felt social Support & & & & $0.030^{*}$ \\
\hline$<$ Sometimes & $18(24)$ & $56(76)$ & $74(21)$ & \\
\hline \multirow[t]{2}{*}{$>$ Sometimes } & $41(14)$ & $241(86)$ & 282(79) & \\
\hline & \multicolumn{3}{|c|}{ Concerns about therapy } & \\
\hline Taking ART worries me & & & & 0.378 \\
\hline Agree & $16(22)$ & $58(78)$ & $74(18)$ & \\
\hline
\end{tabular}


Table 1 Characteristics of respondents (Continued)

\begin{tabular}{|c|c|c|c|c|}
\hline Disagree & $55(17)$ & $264(83)$ & $319(79)$ & \\
\hline Not sure & & & $10(3)$ & \\
\hline I Worry about long-term effects of ART & & & & 0.885 \\
\hline Agree & $31(19)$ & $135(81)$ & $166(41)$ & \\
\hline Disagree & $40(18)$ & $181(82)$ & $221(55)$ & \\
\hline Not sure & & & $16(4)$ & \\
\hline Lack understanding of how ART works & & & & 0.505 \\
\hline Agree & $28(20)$ & $115(80)$ & $143(35)$ & \\
\hline Disagree & $40(17)$ & $197(83)$ & $237(59)$ & \\
\hline Not sure & & & $23(6)$ & \\
\hline Therapy disrupt my life & & & & $0.006^{*}$ \\
\hline Agree & $20(29)$ & $49(71)$ & $69(17)$ & \\
\hline Disagree & $49(15)$ & $274(85)$ & $323(80)$ & \\
\hline Not sure & & & $11(3)$ & \\
\hline I am embarrassed taking ARV & & & & 0.162 \\
\hline Agree & $38(20)$ & $148(80)$ & $186(46)$ & \\
\hline Disagree & $31(15)$ & $175(85)$ & $206(51)$ & \\
\hline \multirow[t]{2}{*}{ Not sure } & & & $11(3)$ & \\
\hline & Reason & $g$ therapy & & \\
\hline Implied missed therapy & & & & $0.001^{*}$ \\
\hline Gave reason for not taking & $50(24)$ & $156(76)$ & $206(51)$ & \\
\hline Never failed & $22(11)$ & $175(89)$ & $197(49)$ & \\
\hline Reason for not taking medicine & & & & $0.000^{*}$ \\
\hline Being busy and forgetting & $44(29)$ & $110(71)$ & $154(38)$ & \\
\hline Hiding from colleagues & $3(60)$ & $2(40)$ & $5(2)$ & \\
\hline Others & $3(6)$ & $44(94)$ & $47(11)$ & \\
\hline
\end{tabular}

*Statistically significant at level $p<0.05$ by chi-square test

\section{Discussion}

The current study assessed non-adherence and factors associated with it in Nairobi, Kenya. Prevalence of nonadherence found in this study (18\%) is comparable to the continental prevalence (23\%) for Africa [1], 21\% in Southwest Ethiopia [2] and 22\% in Cote d'Ivore [3]. But, inconsistent with the findings of Ellis et al. in Kibera, Nairobi (48\%) [12]; Talam et al. in Eldoret (56.8\%) [13] and Munyao et al. in Mombasa [14]. The inconsistency with the findings of Eldoret study was attributed to differences in assessment methods, and inconsistency with the findings of Kibera and Mombasa studies to difference in treatment periods (2005) when ART knowledge among patients and clinicians was low [17].

Table 2 Prevalence of non-adherence to HAART among respondents

\begin{tabular}{lll}
\hline & \multicolumn{2}{l}{ Adherent? } \\
\hline Methods of determining adherence & $\begin{array}{l}\text { Yes; } \boldsymbol{n} \\
\text { (\%) }\end{array}$ & $\begin{array}{l}\text { No; } \boldsymbol{n} \\
\text { (\%) }\end{array}$ \\
\hline a)CASE adherence Index; i.e. $\leq 10$ (non-adherent) & $72(18)$ & $331(82)$ \\
\hline $\begin{array}{l}\text { b)missed at least once a week method (<95 } \\
\text { adherence) }\end{array}$ & $74(18)$ & $329(82)$ \\
\hline
\end{tabular}

In this study, younger respondents below the mean age (39.7 years) were more likely not to adhere to HAART although age did not predict. The finding is consistent with the findings of Iliyasu et al in Nigeria [6], Carballo et al in Spain [9] and Orrell et al in South Africa [7] but, inconsistent with the finding of Talam et al in Eldoret [13]. The inconsistent with Eldoret study can be attributed to difference in mean age; respondents in the Eldoret study were younger (mean age 36.1 years). Better adherence among older adults may be explained by survivor effect in that, individuals who maintain greater compliance with treatment recommendations may actually outlive those who are non-adherent. Proportion of female in this study was two-fold that of male and is similar to the proportion of HIV/AIDS reported in Kenya [18]. However, gender did not predict non-adherence to HAART in Nairobi. These findings correlated with findings of other studies $[5,6,13,19]$. Marital status did not predict non-adherence. Other studies have reported mixed results; Byakika et al found an association between marital status and non-adherence to ARV therapy in Uganda [5] while, Weiser et al in Botswana did not [19]. 
Table 3 Predictors of Non-adherence to HAART among respondents

\begin{tabular}{lllll}
\hline & Crude & & Adjusted & \\
\hline Characteristics & OR $\left(\mathrm{Cl}_{\text {.95 }}\right)$ & $\mathbf{p}$-value & OR (Cl.95) & p-value \\
\hline Proximity to clinic where refilled & $2.740(1.382,5.434)$ & $0.003^{*}$ & 2.387 & $0.019^{* *}$ \\
& & & $(1.155,4.931)$ & $0.011^{* *}$ \\
\hline Reported difficult fitting therapy in own schedule & 2.282 & $0.006^{*}$ & 2.310 & $(1.211-4.408)$ \\
& $(1.250-4.169)$ & & 2.264 & $0.006^{* *}$ \\
\hline Gave reasons for skipping doses & 2.550 & $0.001^{*}$ & $(1.261-4.064)$ & \\
\hline
\end{tabular}

**Statistically significant at level $p<0.05$ by multivariate analysis

Socio-economic factors did not significantly influence adherence in this study. Findings with respect to income were consistent with the findings of Orrell et al in South Africa [7] but inconsistent with findings of Byakika et al in Uganda where patients paid for ART [5]. Finding about formal education was consistent with the findings of Weiser et al in Botswana [19] but, inconsistent with the findings of Carballo et al in Spain [9] where understanding of treatment regimen was poor [10]. Although respondents living in smaller houses were more likely not to adhere to therapy than respondents living in bigger houses, house size did not predict non-adherence. These findings are consistent with findings in other studies $[9,20]$.

In this study, proximity to clinic predicted non-adherence. Respondents who accessed therapy in clinics within a walking distance from their homes were about two and a half times more likely not to adhere than patients who refilled in far away clinics. These findings together with social stigma associated with ART use suggested that most respondents who accessed free therapy in clinics within walking distance to their homes did so due to lack of choice; speculatively, could not afford transport cost to alternative HAART clinics. Where respondents paid for transport, amounts paid did not significantly influence non-adherence to HAART which was consistent with the finding of Byakika et al in Uganda [5]. Most respondents reported felt social support from friends and relatives, and it was therefore hypothesized that these friends and relatives also provided respondents with material support, making it possible to overcome cost barrier that has been associated with non-adherence to therapy in other studies [5]. Such "helpers" have been found to make their expectations for the patients to adherence known, thus, creating a responsibility on the part of patients who consequently, adhered to therapy to promote goodwill with the helpers [21]. Recipients who reported receiving social support were two folds more likely to adhere to therapy than those who did not. These findings are consistent with many ARV therapy adherence studies [16,2,22-25].
Adherence to therapy in this study increased with duration on HAART although did not predict it. This is consistent with findings of Mannheimer et al [15] but, inconsistent with the findings of Byakika et al in Uganda [5]. The inconsistency was attributed to the shorter experience with ARVs and paying for therapy in the Uganda study. Where drugs are paid for, many studies have found shortage of drugs due to economic barriers, as the most common reason for non adherence. The reported adverse effects did not significantly influence non-adherence which was consistent with findings of Weiser et al in Botswana [19], and Aspeling and Van Wyk in South Africa [22]. The findings could be attributed to high ART knowledge and awareness found among respondents in line with the South Africa study in which informed HIV patients tolerated side effects and adhered to therapy [22].

In this study, respondents regarded adherence to HAART extremely important to HIV treatment and translated this knowledge into positive belief about necessity of HIV medication almost universally. Belief in the benefit of therapy found together with availability of free HAART is credited for improved adherence among the respondents. This finding correlates with findings of Aspeling and Van Wyk in South Africa where adequate pre-therapy counselling and HIV education impacted adherence positively [22]. However, giving reason for skipping therapy predicted nonadherence. Three quarters of the respondents who gave reasons for skipping therapy stated being busy and forgetting as the reason and a third of them did not adhere. This finding is consistent with findings of Nieuwkerk et al [26] and Byakika et al in Uganda [5]. Having difficult fitting therapy in own daily schedule predicted non-adherence. Respondents who reported difficult with therapy were more than two folds more likely not to adhere to ARV therapy. This was consistent with the findings of Munro et al [8]. It was speculated, in line with Vervoort et al [24] finding that when medication scheme did not fit in a patient's routine, it caused them to forget to take medications and consequently resulted in poor adherence. 


\section{Conclusion}

Given the complex array of factors associated with nonadherence, no single strategy is likely to be effective for every patient. It is recommended that patients be targeted with comprehensive individualized interventions employing behavioral educational strategies to improve ability to fit therapy in own lifestyle and cue-dose training to impact forgetfulness. Further research is recommended to explain poor adherence among patients accessing therapy from ARV clinics within walking distance from their homes.

\section{List of abbreviations}

AOR: Adjusted Odds Ratio; ART: Antiretroviral Therapy; ARV: Antiretroviral; CCC: Comprehensive Care Centre; COR: Crude Odds Ratio; HAART: Highly Active Antiretroviral Therapy; HIV: Human Immunodeficiency Virus; OR: Odds Ratio.

\section{Acknowledgements}

This study was carried as part of my PhD thesis work. In work of this nature one has many debts to acknowledge. For practical reasons it would be impossible to individually thank all those who through help and advice, generously contributed to its accomplishment. They all appreciate that I cannot adequately thank them. A few of them however deserve special attention. First, special thanks go to my supervisors, Prof. Zipporah Ng'ang'a and Dr. Gabriel Mbugua without whose support, guidance and constructive comments this study could not have been a success. My appreciation also go to the study participants, the management and staff of Kenyatta National Hospital, Kenya Medical Research Institute and Riruta comprehensive care centers for allowing use of the sites for the study. Special thanks also go to the director and staff of the Centre for Microbiology Research of Kenya Medical Research Institute for the valuable comments on the proposal and for allowing its clearance through the centre.

\section{Author details}

IInstitute of Tropical Medicine and Infectious Diseases (ITROMID), Jomo Kenyatta University of Agriculture and Technology (JKUAT), P.O. Box 62000 00200 Nairobi, Kenya. ${ }^{2}$ Centre for Microbiology Research, Kenya Medical Research Institute (KEMRI), P.O Box 1946400200 Nairobi, Kenya.

\section{Authors' contributions}

SNW conceived, designed and conducted study, analysed data and interpreted findings. ZWN and GGM supervised and guided the student. Al authors contributed to the final report and approved the final manuscript.

\section{Competing interests}

The authors declare that they have no competing interests.

Received: 26 March 2011 Accepted: 5 December 2011 Published: 5 December 2011

\section{References}

1. Mills EJ, Nachega JB, Buchan I, Orbinski J, Amir Attaran, Singh S, Rachlis B: Adherence to Antiretroviral Therapy in Sub-Saharan Africa and North America. Journal of the American Medical Association 2006, 296:679-690.

2. Amberbir A, Woldemichael K, Getachew S, Girma B, Deribe K: HIV-infected persons: a prospective study in Southwest Ethiopia. BioMed Central journal of Public Health 2008, 8:265.

3. Eholie SP, Tanon A, Polneau S, Ouiminga M, Djadji A, Kangah-Koffi C, Diakite N, Anglaret X, Kakou A, Bissagnene E: Field Adherence to Highly Active Antiretroviral Therapy in HIV-Infected Adults in Abidjan, Cote d'Ivoire. Journal of Acquired Immune Deficiency Syndrome 2007, 45(3):355-358.

4. Marcellin F, Boyer S, Protopopescu C, Dia A, Ongolo-Zogo P, Koulla-Shiro S, Abega SC, Abe C, Moatti JP, Spire B, Carrieri MP: Determinants of unplanned antiretroviral treatment interruptions among people living with HIV in Yaoundé, Cameroon. Journal of Tropical Medicine and International Health 2008, 13(12):1470-8.

5. Byakika-Tusiime J, Oyugi JH, Tumwikirize WA, Katabira ET, Mugyenyi PN, Bangsberg DR: Adherence to HIV antiretroviral therapy in HIV+ Ugandan patients purchasing therapy. International Journal of STD AIDS 2005, 16:38-41.

6. Iliyasu Z, Kabir M, Abubakar IS, Babashani M, Zubair ZA: Compliance to antiretroviral therapy among AIDS patients in Aminu Kano Teaching Hospital, Kano, Nigeria. Nigeria Journal of Medicine 2005, 14:290-294.

7. Orrell C, Bangsberg DR, Badri M, Wood R: Adherence is not a barrier to successful antiretroviral therapy in South Africa. Journal of Acquired Immune Deficiency Syndromes 2003, 17:1369-1375.

8. Munro SA, Lewin SA, Smith HJ, Engel ME, Fretheim A: Patient Adherence to Tuberculosis Treatment: A Systematic Review of Qualitative Research. Journal of Public Library of Science (PLoS) Medicine 2007, 4(7):1230-1245.

9. Carballo E, Cadarso-Suárez C, Carrera I, Fraga J, De La Fuente J, Ocampo A Ojea R, Prieto A: Assessing relationships between health-related quality of life and adherence to antiretroviral therapy. Quality of Life Research 2004, 13(3):587-599.

10. Murri R, Ammassari A, Trotta MP, De Luca A, Melzi S, Minardi C, Zaccarelli M, Rellecati P, Santopadre P, Soscia F, Scasso A, Tozzi V, Ciardi M, Orofino GC, Noto P, Monforte A, Antinori A, Wu AW: Patient-reported and physician-estimated adherence to HAART: social and clinic centerrelated factors are associated with discordance. Journal of General Internal Medicine 2004, 19:1104-10.

11. WHO/UNAIDS/UNICEF: 'Towards Universal Access: Scaling up priority HIV/ AIDS interventions in the health sector'. 2009.

12. Ellis $A E$, Gogel RP, Roman BR, Watson JB, Indyk D, Rosenberg G: A CrossSectional Study of Adherence to Short-Term Drug Regiments in Urban Kenya. Social Work Health Care 2006, 42(3-4):237-50.

13. Talam NC, Gatongi P, Rotich J, Kimaiyo S: Factors Affesting Antiretroviral Drug Adherence Among HIV/AIDS Adult patients Attending HIV/AIDS Clinic At Moi Teaching And Referral Hospital, Eldoret, Kenya. East African Journal of Public Health 2008, 5(2):74-78.

14. Munyao P, Sarna A, Luchters S, Geibel S, Shikely K, Mandaliya K, Kaai S, Hawken M, van Dam J, Temmerman M: "How feasible is a DAART strategy to promote adherence to ART?: Lessons from Mombasa, Kenya". Horizons Research Update Nairobi: Population Council; 2005.

15. Mannheimer SB, Mukherjee R, Hirschhorn LR, Dougherty J, Celano SA, Ciccarone D, Graham KK, Mantell JE, Mundy LM, Eldred L, Botsko M, Finkelstein R: The CASE adherence index: A novel method for measuring adherence to antiretroviral therapy. AIDS Care 2006, 18:853-861.

16. WHO: Adherence to long-term therapies: evidence for action 2003, Report

17. IRIN: Kenya: treatment literacy lagging behind ARV rollout. IRIN/PlusNews Wednesday, October 102007.

18. National AIDS Control Council and Office of the President, Kenya: UNGASS Country Report for Kenya. NACC 2008, Nairobi.

19. Weiser S, Wolfe W, Bangsberg D, Thior I, Gilbert P, Makhema J, Kebaabetswe P, Dickenson D, Mompati K, Essex M, Marlink R: Barriers to Antiretroviral Adherence for Patients Living with HIV Infection and AIDS in Botswana. Journal of Acquired Immune Deficiency Syndrome 2003, 34:281-288.

20. Bangsberg DR, Moss AR, Deeks SG: Paradoxes of adherence and drug resistance to HIV antiretroviral therapy. Journal of Antimicrobial Chemotherapy 2004, 53:696-699.

21. Ware NC, Idoko J, Kaaya S, Biraro IA, Wyatt MA: Explaining Adherence Success in Sub-Saharan Africa: An Ethnographic Study. Journal of Public Library of Science (PLOS) Medicine 2009, 6(1):e100001.

22. Aspeling HE, van Wyk NC: Factors associated with adherence to antiretroviral therapy for the treatment of HIV-infected women attending an urban care facility. International Journal of Nursing Practice 2008, 14:3-10.

23. Remien RH, Hirky AE, Johnson MO, Weinhardt LS, Whittier D, Le GM: Adherence to medication treatment: a qualitative study of facilitators and barriers among a diverse sample of HIV+ men and women in four US cities. AIDS and Behavior 2003, 7(1):61-72.

24. Vervoort SCJ, Borleffs JCC, Hoepelman AIM, Grypdonck MHF: Adherence in antiretroviral therapy: a review of qualitative studies. International Journal of STD AIDS 2007, 21:271-281.

25. Ammassari A, Trotta MP, Murri R, Castelli F, Narciso P, Noto P, Vecchiet J, D'Arminio MA, WU AW, Antinori A: Correlates and predictors of 
adherence to highly active antiretroviral therapy: overview of published literature. Journal of Acquired Immune Deficiency Syndromes 2002, 31:

S123-S127.

26. Nieuwkerk P, Sprangers M, Burger D, Hoetelmans RM, Hugen PW, Danner SA, van Der Ende ME, Schneider MM, Schrey G, Meenhorst PL, Sprenger HG, Kauffmann RH, Jambroes M, Chesney MA, de Wolf $F$, Lange JM, the ATHENA Project: Limited Patient Adherence to Highly Active Antiretroviral Therapy for HIV-1 Infection in an Observational Cohort Study. Archives of Internal Medicine 2001, 161(16):1962-1968.

doi:10.1186/1742-6405-8-43

Cite this article as: Wakibi et al:: Factors associated with non-adherence to highly active antiretroviral therapy in Nairobi, Kenya. AIDS Research and Therapy 2011 8:43.

\section{Submit your next manuscript to BioMed Central} and take full advantage of:

- Convenient online submission

- Thorough peer review

- No space constraints or color figure charges

- Immediate publication on acceptance

- Inclusion in PubMed, CAS, Scopus and Google Scholar

- Research which is freely available for redistribution

Submit your manuscript at www.biomedcentral.com/submit 